\title{
Pozycja ustrojowa sekretarza gminy
}

\section{Uwagi ogólne}

Podstawę prawną funkcjonowania w polskim systemie administracyjnym instytucji sekretarza gminy stanowi przede wszystkim ustawa $\mathrm{z}$ dnia 21 listopada 2008 r. o pracownikach samorządowych ${ }^{2}$ oraz ustawa $\mathrm{z}$ dnia 8 marca 1990 r. o samorządzie gminnym ${ }^{3}$. Niemniej jednak przepisy nakładające na sekretarzy gminy uprawnienia i obowiązki wychodzą także poza ramy gałęzi prawa administracyjnego. Znajdziemy je choćby w prawie cywilnym (art. 951 ustawy z dnia 23 kwietnia 1964 r. - Kodeks cywilny) $)^{4}$ czy przepisach prawa pracy (dla przykładu art. 100, 129 i 177 ustawy z dnia 26 czerwca 1974 r. - Kodeks pracy) $)^{5}$.

Sekretarz gminy nie jest organem gminy, a jedynie pracownikiem samorządowym zatrudnianym na podstawie umowy o pracę, co stanowi ewolucję $\mathrm{w}$ zestawieniu z przepisami nieobowiązującej już ustawy z dnia 22 marca 1990 r. o pracownikach samorządowych ${ }^{6}$, według której zawierał stosunek pracy $\mathrm{z}$ urzędem gminy $\mathrm{w}$ drodze powołania, uchwałą rady gminy na wniosek wójta?

Obecnie obsadzenie stanowiska sekretarza jest obligatoryjne ${ }^{8}$ w każdej gminie (wiejskiej, miejsko-wiejskiej, miejskiej iw miastach na prawach

\footnotetext{
${ }^{1}$ Agnieszka Kania, studentka, Uniwersytet Pedagogiczny im. Komisji Edukacji Narodowej w Krakowie, Wydział Politologii, Instytut Prawa, Administracji i Ekonomii Społecznej.

${ }^{2}$ Tekst jedn.: Dz.U. z 2018 r. poz. 1260 ze zm., dalej jako u.p.s.

${ }^{3}$ Tekst jedn.: Dz.U. z 2018 r. poz. 994 ze zm., dalej jako u.s.g.

${ }^{4}$ Tekst jedn.: Dz.U. z 2018 r. poz. 1025 ze zm., dalej jako k.c.

${ }^{5}$ Tekst jedn.: Dz.U. z 2018 r. poz. 917 ze zm., dalej jako k.p.

${ }^{6}$ Dz.U. Nr 21, poz. 124; uchylona z dniem 1 stycznia 2009 r.

${ }^{7}$ Z. Leoński, Samorzą terytorialny w RP, Warszawa 2006, s. 131.

${ }^{8}$ P. Groński, Komentarz do art. 5 [w:] Ustawa $z$ dnia 21 listopada 2008 r. o pracownikach samorządowych (Dz.U. Nr 223, poz. 1458). Komentarz, Warszawa 2010, s. 64.
} 
powiatu). Wcześniejsza praktyka i orzecznictwo administracyjne opowiadały się za koniecznością „utworzenia i obsadzenia” stanowiska sekretarza, ale brakowało w tym względzie podstawy prawnej ${ }^{9}$. Przepisy prawa nie przewidują natomiast utworzenia instytucji zastępcy sekretarza gminy ${ }^{10}$.

Piastowanie stanowiska sekretarza gminy jest wykonywaniem funkcji publicznej, na co wskazuje szeroka interpretacja pojęcia „określonych spraw gminy" $\mathrm{z}$ art. 33 ust. 4 u.s.g., dzięki któremu wójt jest uprawniony do powierzenia sekretarzowi wykonywania spraw gminy należących do jego właściwości. Dlatego też informacje dotyczące zatrudnienia sekretarza gminy są informacjami publicznymi (np. zarobki) ${ }^{11}$. Na wstępie warto również wspomnieć, że wszelkie informacje dotyczące dokumentów urzędowych, na podstawie których sekretarz gminy wykonuje powierzone mu przez wójta zadania, podlegają ogólnemu reżimowi ustawy z dnia 6 września $2001 \mathrm{r}$ o dostępie do informacji publicznej ${ }^{12} \mathrm{i}$ powinny być udostępnione obywatelowi niezwłocznie, a najpóźniej w terminie do 14 dni od złożenia wniosku (art. 13 u.d.i.p.).

\section{Uwagi szczegółowe}

\subsection{Warunki zatrudnienia sekretarza gminy}

Osoba ubiegająca się o zatrudnienie w charakterze sekretarza gminy musi spełnić określone warunki przewidziane w przepisach prawa. Przesłanki zatrudnienia wymienia art. 5 ust. 2 u.p.s., który należy interpretować w związku z brzmieniem art. 6 ust. 1, 3 pkt 2 i 3 oraz ust. 4 u.p.s. Zasadniczo osoba taka powinna wcześniej co najmniej cztery lata być pracownikiem samorządowym, zatrudnionym w co najmniej jednej z następujących jednostek: w urzędzie marszałkowskim, starostwie powiatowym, urzędzie gminy, wojewódzkiej lub powiatowej jednostce organizacyjnej, samorządowym zakładzie budżetowym, gminnej jednostce pomocniczej lub budżetowej, biurze związku jednostek samorządu terytorialnego (ewentualnie strukturze mu odpowiadającej), biurze samorządowego zakładu budżetowego związku jednostek samorządu terytorialnego czy biurze innych komórek administracyjnych jednostek samorządu terytorialnego. Uprawnienie to przysługuje jednak tylko pracownikom samorządowym, którzy legitymują się czteroletnim stażem pracy na stanowisku urzędniczym. Przesłanka ta wyłącza ex lege możliwość ubiegania się o stanowisko sekretarza gminy przez doradców, asystentów czy pracowników samorządowych zatrudnio-

${ }^{9}$ A. Szewc, T. Szewc, Komentarz do art. 5 [w:] Ustawa o pracownikach samorządowych. Komentarz, A. Szewc (red.), Warszawa 2011, s. 90.

${ }^{10}$ A. Wierzbica, Pozycja ustrojowa sekretarza jednostki samorządu terytorialnego „Studia Prawno-Ekonomiczne” 2009, t. LXXIX, s. 36.

${ }^{11}$ Wyrok WSA z dnia 14 listopada 2012 r., II SA/Gd 544/12, LEX nr 1228222.

${ }^{12}$ Tekst jedn.: Dz.U. z 2018 r. poz. 1330 ze zm., dalej jako u.d.i.p. 
nych na stanowiskach pomocniczych i obsługi, nawet jeżeli długość ich stażu pracy jest równa bądź większa niż cztery lata (wniosek z art. 5 ust. 2 w zW. z art. 4 ust. 2 u.p.s.).

Ponadto aby zostać sekretarzem gminy, należy co najmniej od dwóch lat zajmować kierownicze stanowisko urzędnicze w wymienionych jednostkach lub jednostkach sektora finansów publicznych (wymienionych $\mathrm{w}$ art. 9 ustawy o finansach publicznych ${ }^{13}$ ). Natomiast aby móc ubiegać się o kierownicze stanowisko urzędnicze, trzeba posiadać kwalifikacje potwierdzone dyplomem ukończenia studiów pierwszego lub drugiego stopnia $^{14}$ lub trzyletni staż pracy, który odpowiada swoim charakterem wymaganiom stawianym przed określonym stanowiskiem, bądź trzy lata wykonywać działalność gospodarczą o zbieżnym z wymaganiami stanowiska charakterze. W przypadku sekretarza gminy wspomniany charakter wymagań jest określany szeroko, ponieważ interpretacja przepisów prawa daje możliwość powierzenia osobie zatrudnionej na stanowisku sekretarza gminy większości spraw gminy - o czym szerzej będzie mowa poniżej.

Należy podkreślić, że kandydat na stanowisko sekretarza gminy musi spełniać także warunki zatrudnienia przewidziane dla każdego innego pracownika samorządowego, a mianowicie posiadać pełną zdolność do czynności prawnych i określone kwalifikacje zawodowe, korzystać z pełni praw publicznych, które umożliwią mu prawidłowe wykonywanie pracy na stanowisku sekretarza gminy, oraz odznaczać się nieposzlakowaną opinią. Sekretarzem nie może zostać osoba skazana prawomocnym wyrokiem sądu za umyślne przestępstwo ścigane $\mathrm{z}$ oskarżenia publicznego lub umyślne przestępstwo skarbowe (art. 6 u.p.s.).

Polski ustawodawca nie stworzył legalnej definicji nieposzlakowanej opinii, pozostaje ona pojęciem nieostrym. Przy interpretacji tej przesłanki należy analizować każdy przypadek oddzielnie. Wykładnia musi być oparta na konkretnych zdarzeniach, zachowaniach, nigdy nie może dotyczyć po-

${ }^{13}$ Zgodnie z art. 9 ustawy o finansach publicznych: „Sektor finansów publicznych tworzą: 1) organy władzy publicznej, w tym organy administracji rządowej, organy kontroli państwowej i ochrony prawa oraz sądy i trybunały; 2) jednostki samorządu terytorialnego oraz ich związki; 2a) związki metropolitalne; 3) jednostki budżetowe; 4) samorządowe zakłady budżetowe; 5) agencje wykonawcze; 6) instytucje gospodarki budżetowej; 7) państwowe fundusze celowe; 8) Zakład Ubezpieczeń Społecznych i zarządzane przez niego fundusze oraz Kasa Rolniczego Ubezpieczenia Społecznego i fundusze zarządzane przez Prezesa Kasy Rolniczego Ubezpieczenia Społecznego; 9) Narodowy Fundusz Zdrowia; 10) samodzielne publiczne zakłady opieki zdrowotnej; 11) uczelnie publiczne; 12) Polska Akademia Nauk i tworzone przez nią jednostki organizacyjne; 13) państwowe i samorządowe instytucje kultury; 14) inne państwowe lub samorządowe osoby prawne utworzone na podstawie odrębnych ustaw w celu wykonywania zadań publicznych, z wyłączeniem przedsiębiorstw, instytutów badawczych, banków i spółek prawa handlowego".

${ }^{14}$ Art. 2 ustawy z dnia 27 lipca 2005 r. - Prawo o szkolnictwie wyższym, tekst jedn.: Dz.U. z 2017 r. poz. 2183 ze zm., art. 2. 
glądów, wyznawanej religii, orientacji seksualnej czy stosunków osobisto-rodzinnych. Konkretne czyny muszą być uznawane za niegodne lub nieuczciwe w opinii społecznej ${ }^{15}$. Jednak z całą pewnością jest ona czymś więcej niż tylko brakiem skazania za przestępstwo, co wynika z przepisów prawa, wyodrębniających skazanie za przestępstwo umyślne ścigane z oskarżenia publicznego (ewentualnie przestępstwo skarbowe), jak i z orzecznictwa ${ }^{16}$. Nie można jej również zawężać do pozbawienia praw publicznych, które orzeka się $\mathrm{w}$ związku $\mathrm{z}$ czynem zabronionym dokonanym $\mathrm{z}$ pobudek zasługujących na szczególne potępienie (art. 40 ustawy z dnia 6 czerwca 1997 r. - Kodeks karny $\left.{ }^{17}\right)^{18}$.

W tym miejscu pojawia się potrzeba zwrócenia uwagi na wymóg posiadania przez osobę ubiegającą się o stanowisko sekretarza gminy obywatelstwa polskiego. Zgodnie $\mathrm{z}$ wykładnią literalną art. 6 ust. 1 pkt 1 u.p.s. co do zasady cudzoziemcy, czyli osoby nieposiadające obywatelstwa polskiego (definicja legalna znajduje się $\mathrm{w}$ art. 3 ustawy z dnia 12 grudnia $2013 \mathrm{r}$. o cudzoziemcach ${ }^{19}$ ), nie mogą zostać sekretarzami gminy.

Należy zauważyć, że cudzoziemcy traktowani są w myśl przepisów przywołanej ustawy bardzo szeroko, w pojęciu tym mieszczą się nie tylko osoby dysponujące obywatelstwem innego państwa, ale także apatrydzi i osoby o nieokreślonym obywatelstwie ${ }^{20}$, jak również posiadające w Rzeczypospolitej Polskiej status uchodźcy. Nie jest ważne dla interpretacji pojęcia „cudzoziemiec” posiadanie przez daną osobę kilku obywatelstw. Kryterium oceny stanowi wyłącznie ustawa polska ${ }^{21}$.

Zgodnie z art. 45 Traktatu o Funkcjonowaniu Unii Europejskiej ${ }^{22}$ obywatele Unii Europejskiej mają prawo do swobodnego ubiegania się o rzeczywiście oferowane miejsca pracy na terytorium Rzeczypospolitej Polskiej bez żadnej formy dyskryminacji. Niemniej art. 45 Traktatu wyłącza to uprawnienie $\mathrm{w}$ stosunku do miejsc pracy w administracji publicznej. Obywatele UE (jak i innych państw, z którymi RP jest związana stosownymi umowami międzynarodowymi) nie mogą ubiegać się więc o stanowiska w administracji publicznej, na które nawiązanie stosunku pracy odbywa się w drodze wyboru i powołania. Dzieje się tak dlatego, że cudzoziemcy nie

${ }^{15}$ M. Rotkiewicz, Komentarz do art. 6 [w:] Ustawa o pracownikach samorzadowych. Komentarz, Warszawa 2016, s. 19-21.

${ }^{16}$ M. Rotkiewicz, Komentarz do art. 6..., s. 19-20; wyrok SN z dnia 16 października 2009 r., I PK 85/09, http://www.sn.pl/sites/orzecznictwo/orzeczenia1/i\%20pk\%20 85-09-1.pdf (7.12.2017).

17 Tekst jedn. Dz.U. z 2018 r. poz. 2204 ze zm.

${ }^{18}$ M. Rotkiewicz, Komentarz do art. 6..., s. 19.

${ }^{19}$ Tekst jedn.: Dz.U. z 2018 r. poz. 2206 ze zm.

${ }^{20}$ M. Lewicki, Cudzoziemcy [w:] Materialne prawo administracyjne. Pojęcia, instytucje, zasady, M. Stahl (red.), Warszawa 2002, s. 109.

${ }^{21}$ P. Stachańczyk, Komentarz do art. 2 [w:] Prawo o cudzoziemcach. Komentarz, J. Chlebny (red.), Warszawa 2006, s. 8.

${ }^{22}$ Dz.Urz. UE z 2016 r. C 202, s. 47. 
mogą zajmować stanowisk mających najistotniejszy wpływ na zabezpieczenie generalnych (ogólnych, powszechnych, zbiorowych) interesów państwa i brać udziału w chociażby pośrednim sprawowaniu władzy. Mogą więc zajmować stanowiska tylko na podstawie umowy o pracęe $e^{23}$, co bezpośrednio koresponduje $\mathrm{z}$ art. 11 ust. 2 i 3 u.p.s.

Zgodnie z taką wykładnią przepisów traktatowych i krajowych (art. 6 w zw. z art. 11 ust. 2 i 3 u.p.s.) należy stwierdzić, że obywatele państw, z którymi Rzeczpospolita Polska zawarła stosowne umowy międzynarodowe, jak i obywatele Unii Europejskiej mogą ubiegać się o stanowisko sekretarza gminy. Jednak $\mathrm{w}$ porównaniu $\mathrm{z}$ poprzednim brzmieniem przepisów ustawy regulującej nawiązanie stosunku pracy $\mathrm{z}$ urzędem gminy przez sekretarza $\mathrm{w}$ drodze powołania ${ }^{24}$ można pokusić się o stwierdzenie, że prawo do ubiegania się o stanowisko sekretarza przez cudzoziemców w procesie upowszechniania informacji o wolnych stanowiskach przez wójta na mocy art. 11 ust. 2 u.p.s. może zostać ograniczone. Motywowane jest to rangą i szerokim zakresem spraw, które mogą zostać powierzone sekretarzowi gminy. Jednak przyjęcie tej wykładni za bardzo ograniczałoby proponowaną przez Trybunał Sprawiedliwości Unii Europejskiej wąską interpretację pojęcia zatrudnienia w administracji publicznej ${ }^{25}$.

Co więcej, należy podkreślić, że „działalność” sekretarza gminy nie jest wykonywaniem władzy publicznej, a tylko zadań powierzonych sekretarzowi przez jego bezpośredniego zwierzchnika - kierownika urzędu (wójta, burmistrza, prezydenta miasta), który sprawuje pieczę nad całością spraw społeczności gminnej.

Niemniej obywatele państw członkowskich UE mogą wybierać i zostać wybranymi do organów przedstawicielskich samorządu terytorialnego (w kontekście sekretarza gminy - rady gminy), a ustawa o pracownikach samorządowych ogranicza tylko podejmowanie pracy zawodowej, a nie obejmowanie funkcji związanych z wykonywaniem władzy lokalnej ${ }^{26}$.

Warto zauważyć, że art. 11 ust. 3 in fine wprowadza obowiązek posiadania dokumentu potwierdzającego znajomość języka polskiego. Należy więc zaznaczyć, że sekretarz gminy musi posługiwać się w sposób komunikatywny językiem polskim, niezależnie od swojego obywatelstwa. Nie ma jednak przeszkody, by sekretarzem gminy została osoba posiadająca podwójne (wielokrotne) obywatelstwo ${ }^{27}$, szczególnie gdy jednym z nich jest obywatelstwo polskie.

${ }^{23}$ J. Stelina, Komentarz do art. 11 [w:] Ustawa o pracownikach samorządowych. Komentarz, M. Rycak, A. Rycak, J. Stelina (red.), Warszawa 2016, s. 91-92.

${ }^{24}$ Ustawa z dnia 22 marca 1990 r. o pracownikach samorządowych.

${ }^{25}$ J. Stelina, Komentarz do art. 11..., s. 92.

${ }^{26}$ P. Groński, Komentarz do art. 11..., s. 87.

${ }^{27}$ Zasada wyłączności obywatelstwa polskiego oznacza, że zgodnie z polskim prawem władza publiczna traktuje osobę posiadającą podwójne (wielokrotne) obywatelstwo jak osobę posiadającą tylko obywatelstwo polskie [w:] P. Ruczkowski, Obywatel- 


\subsection{Problem zakresu zadań powierzanych sekretarzowi gminy na mocy art. 33 ust. 4 u.s.g.}

Sekretarz gminy nie jest organem gminy, nie ma więc samoistnych kompetencji ${ }^{28}$, a wykonuje jedynie zadania nadane mu przez przepisy ustawowe, a przede wszystkim powierzone na mocy regulaminów gminnych i wyraźnych ${ }^{29}$ upoważnień wójta (burmistrza, prezydenta miasta). Zakres zadań, które ma obowiązek wykonywać sekretarz gminy, powinien być zawsze precyzyjnie określony, nieważne, czy ma swoje źródło w regulaminie organizacyjnym czy innym dokumencie ${ }^{30}$. W literaturze podkreśla się różnice między pojęciem zadania a kompetencji. Kompetencja rozumiana jest jako „zespół praw i obowiązków organu, obejmujący prawne formy działania, głównie o charakterze władczym"31, natomiast zadanie jest celem, który ma zostać osiągnięty, nałożonym na określone organy samorządowe i urzędy przez ustawodawcę ${ }^{32}$. Organ jest gwarantem prawidłowego wykonania danego zadania, to na nim spoczywa odpowiedzialność za należyte wykonanie, jednak może (a właściwie ze względu na rozbudowaną rolę administracji - musi) powierzyć realizację zadań pracownikom urzędu. Jak stanowi art. 33 ust. 1 u.s.g., wójt wykonuje zadania określone przez ustawodawcę przy pomocy pracowników urzędu gminy.

Sekretarzowi gminy wójt może powierzyć prowadzenie określonych spraw gminy. Zgodnie z wykładnią literalną, popartą wykładnią systemową, należy stwierdzić, że „określone sprawy gminy” powinno się interpretować wąsko, jako sprawy urzędu gminy. Motywowane jest to faktem, że art. 33 stanowi o tym, iż wójt jako kierownik urzędu nadaje mu regulamin organizacyjny, jest zwierzchnikiem służbowym osób zatrudnionych w urzędzie, przy jego pomocy wykonuje swoje zadania i wreszcie może powierzyć swojemu zastępcy lub sekretarzowi gminy prowadzenie określonych spraw gminy, które będą oni wykonywali każdorazowo w imieniu wójta. Nie przekazuje więc odpowiedzialności za realizację swych zadań; powierzenie nie tworzy także żadnych kompetencji. Nie dochodzi tu do delegacji uprawnień, a jedynie do ich dekoncentracji ${ }^{33}$. Problemem pozo-

stwo polskie [w:] Prawo administracyjne, M. Zdyb, J. Stelmasiak (red.), Warszawa 2016, s. 553; w kontekście pracownika samorządowego pisze o tym również P. Groński, Komentarz do art. $11 \ldots$, s. 88 .

${ }^{28}$ R. Szarek, Glosa do postanowienia SN z dnia 9 lipca 2009 r., III CZP 19/09, „Samorząd Terytorialny" 2010, nr 9, s. 76-79.

${ }^{29}$ A. Rycak, Komentarz do art.5 [w:] Ustawa..., M. Rycak, A. Rycak, J.Stelina (red.), s.37.

${ }^{30}$ R. Budzisz, Komentarz do art. 33 [w:] Ustawa o samorządzie gminnym. Komentarz, P. Chmielnicki (red.), Warszawa 2013, s. 539.

${ }^{31}$ M. Augustyniak, Samorzad terytorialny [w:] Prawo administracyjne..., s. 383.

${ }^{32}$ Ibidem, s. 383.

${ }^{33}$ Wyrok WSA w Poznaniu z dnia 5 listopada 2015 r., I SA/Po 1753/15, LEX nr 1932546; wyrok NSA z dnia 24 września 2015 r., II OSK 176/14, LEX nr 1987059; 
stają zakres i granice tej dekoncentracji. Jak widać, regulacja art. 33 odnosi się wyłącznie do kwestii związanych z urzędem gminy, dlatego można domniemywać, iż racjonalny ustawodawca, sytuując przekazanie „określonych spraw gminy" w tym artykule, chciał zawęzicic interpretację tego pojęcia, pozostawiając go jednak niedookreślonym ze względu na dynamiczny rozwój administracji i służby świadczonej przez urzędy gminy na rzecz społeczności lokalnej. Za określone sprawy gminy, które mogą zostać powierzone sekretarzowi gminy, należy uznać więc sprawy wykonywane przez wójta jako kierownika urzędu, a nie organ administrujący.

Orzecznictwo sądowe nie popiera jednak rozgraniczania instytucji wójta na organ administracyjny i kierownika urzędu gminy, twierdząc, że kompetencje kierownika urzędu należą do wójta jako do abstrakcyjnie rozumianego organu gminy, który ma obowiązek wykonywać określone zadania, a nie do osoby, która pełni funkcje organu ${ }^{35}$. Zdaniem WSA dla dualizmu kompetencji skupionego $\mathrm{w}$ instytucji wójta nie ma znaczenia pełnienie funkcji wójta przez jedną osobę, a wręcz należy abstrahować od rozumienia tej instytucji przez pryzmat czynnika ludzkiego. Nie ma więc przeszkód, aby kompetencje organu i kierownika urzędu traktować oddzielnie. Dzieje się tak, ponieważ kompetencje wykonywane przez organ gminy mają służyć prawidłowemu administrowaniu i wykonywaniu zadań samorządu gminnego, sprawowaniu władzy w gminie, a kierownik urzędu sprawuje pieczę przede wszystkim nad sprawnym funkcjonowaniem danej jednostki i prawidłowym zarządzaniem zasobami ludzkimi. Chociaż te dwie funkcje mają podobny zakres i niemożliwy jest ich dychotomiczny podział, to jednak pole i cel ich działania są różne.

Na poparcie tego stanowiska można przywołać poglądy doktryny, mówiące, że w sporach między gminą a wójtem reprezentantem gminy jest co do zasady sekretarz, może on także w takim przypadku udzielić pełnomocnictwa procesowego innej osobie ${ }^{36}$. Zaznaczyć należy, że wykonuje on tutaj swoje obowiązki w stosunku do urzędu gminy jako swojego pracodawcy, a nie urzędu administracyjnego powołanego do pomocy organowi administracyjnemu. Sekretarz gminy wykonuje także wszystkie czynności, które są związane ze stosunkiem pracy, oprócz jego nawiązania i rozwiązania, jeżeli nie zostały zastrzeżone na rzecz innego pracownika samorządowego $^{37}$. Ustawodawca, kreując te obowiązki i powierzając ich wykonywanie

wyrok NSA z dnia 24 kwietnia 2002 r., II SA 2092/01, LEX nr 81800; wyrok WSA w Białymstoku z dnia 15 marca 2005 r., II SA/Bk 804/04, LEX nr 150811; wyrok NSA z dnia 3 grudnia 2008 r., II OSK 1458/08, CBOSA.

${ }^{34}$ Zawężającą interpretację „określonych spraw gminy” z art. 33 ust. 4 u.s.g. krytykuje B. Dolnicki, Wpływ nowych zasad wyboru wójta (burmistrza, prezydenta miasta) na relację z rada gminy „,Przegląd Prawa Publicznego”, Warszawa 2007, nr 1-2, s. 83.

${ }^{35}$ Wyrok WSA w Poznaniu z dnia 5 listopada 2015 r., I SA/Po 1753/15.

${ }^{36}$ M. Augustyniak, Samorząd..., s. 397.

${ }^{37}$ Ibidem, s. 397. 
pracownikowi samorządowemu, zezwala na domniemanie tych kompetencji na rzecz sekretarza ${ }^{38}$. Wskazuje to na fakt, że ustawodawca chciał, aby głównym obowiązkiem sekretarza były sprawy urzędu gminy jako jego pracodawcy, a nie organu administrującego. Przemawia to za ujmowaniem instytucji sekretarza gminy w kontekście zwierzchnika urzędu, powołanego do pomocy kierownikowi w osobie wójta.

Interpretując art. 33 ust. 4 u.s.g. $w$ zw. $z$ art. 5 ust. 4 u.p.s., należy stwierdzić, że zadania powierzone sekretarzowi na mocy upoważnienia wójta nie powinny podlegać wykładni zawężającej tylko do organizacji pracy urzędu gminy czy zarządzania zasobami ludzkimi. Wskazuje na to użycie przez ustawodawcę sformułowania „w szczególności”, nie jest to więc wyliczenie enumeratywne spraw, którymi może zająć się sekretarz gminy. Jednak niewątpliwie powinien on jako „pierwszy urzędnik” czuwać przede wszystkim nad zagadnieniami organizacyjnymi pracy urzędu. Potwierdza to praktyka, sytuując sekretarza gminy w komórkach zajmujących się organizacją urzędu ${ }^{39}$.

Za inną wykładnią opowiada się orzecznictwo ${ }^{40}$ i doktryna ${ }^{41}$ - sprawy gminy $\mathrm{z}$ art. 33 ust. 4 u.s.g. powinny być interpretowane możliwie szeroko. Nie należy zawężać ich więc tylko do funkcjonowania urzędu gminy. Wójt bowiem, powierzając swoje kompetencje, nie oddaje ich i ponosi za nie pełną odpowiedzialność, nawet jeżeli fizycznie ich nie wykonuje. Do zadań sekretarza gminy będą więc mogły należeć wszystkie zadania o charakterze publicznym wykonywane przez gminę, które przepis szczególny zastrzega na rzecz kompetencji wójta.

Ponadto podkreśla się, że pojęcie urzędu gminy powinno być ujmowane szeroko, a nie tylko jako zakład pracy, miejsce, gdzie praca jest świadczona $^{42}$. Natomiast zakres spraw należących do zadań sekretarza gminy każda gmina może określać na podstawie wewnętrznych aktów prawnych, szczególnie w regulaminach.

Nie ma więc przeszkód do powierzenia sekretarzowi zadań, które należą do kompetencji wójta, np. w zakresie reprezentacji gminy na zewnątrz ${ }^{43}$ (na podstawie ustawy o samorząadzie gminnym katalog podmiotów, które są uprawnione do tego, aby reprezentować gminę na zewnątrz w charakterze przedstawiciela, nie jest zamknięty, a uprawnienie to nadaje konkretnej

${ }^{38}$ A. Rycak, Komentarz do art. 5..., s. 39.

${ }^{39}$ Por. załącznik do regulaminu organizacyjnego Urzędu Gminy w Zembrzycach wprowadzonego zarządzeniem z dnia 30 czerwca 2015 r. Wójta Gminy Zembrzyce nr $89 / 2015$ r.

${ }^{40}$ Wyrok WSA w Poznaniu z dnia 5 listopada 2015 r., I SA/Po 1753/15.

${ }^{41}$ C. Martysz, Komentarz do art. 33 [w:] Ustawa o samorzadzie gminnym. Komentarz, B. Dolnicki (red.), Warszawa 2016, s. 747.

${ }^{42}$ Wyrok NSA z dnia 24 września 2015 r., II OSK 176/14.

${ }^{43}$ Zarządzenie z dnia 1 grudnia 2015 r. nr 80/2015 Wójta Gminy Budzów w sprawie: upoważnienia i powierzenia spraw Sekretarzowi Gminy; zarządzenie z dnia 25 lipca 2017 r. nr 74/2017 Wójta Gminy Zembrzyce w sprawie udzielenia pełnomocnictwa Sekretarzowi Gminy Zembrzyce. 
osobie pełnomocnictwo wójta ${ }^{44}$ ), co potwierdza praktyka (reprezentacja gminy oznacza wykonywanie czynności o charakterze publicznym, nie prywatnocywilnym; natomiast oświadczenia woli dotyczące zarządu mieniem gminy powinny być składane przez wójta lub jego zastępcę ${ }^{45}$ ), czy nawet wydawania decyzji w sprawach indywidualnych. Jednak powinno się to dokonywać tylko na rzecz podmiotów enumeratywnie wymienionych w art. 33 ust. 4 u.s.g., ponieważ ustawodawca zamknął podmiotowo krąg osób, na rzecz których wójt może cedować swoje kompetencje ${ }^{46}$. Wśród nich znajdziemy zastępcę wójta i sekretarza gminy. Natomiast sekretarz nie może scedować uprawnienia do wydawania decyzji administracyjnych na mocy upoważnienia wójta na inny podmiot, bowiem jest mu ono udzielone w ramach tzw. dekoncentracji wewnętrznej na mocy art. 39 u.s.g., zakazującej takich praktyk ${ }^{47}$.

Wyraźne upoważnienie wójta wynikające z tych przepisów nie odnosi się tylko do wydawania decyzji administracyjnych. Taka interpretacja byłaby błędna $\mathrm{z}$ powodu podstawy zawartej w art. 39 ust. 2 u.s.g., powodowałaby więc powtórzenie uprawnienia wójta do powierzenia swoich kompetencji w tym zakresie sekretarzowi gminy ${ }^{48}$, co kłóciłoby się z dyrektywą zwięzłości tekstu prawnego.

Jednak poza ramy niniejszego pojęcia wychodzi prowadzenie spraw gminy przez tzw. czynności przygotowujące. Nie ma podstaw w art. 33 ust. 4 u.s.g., by zastrzegać je tylko na rzecz sekretarza gminy czy zastępcy wójta. Czynności dotyczące fizycznego sporządzenia wniosku mogą wykonywać inni pracownicy urzędu i nie dochodzi tu do przekazywania kompetencji ani ich materialnej realizacji ${ }^{49}$.

Warto dodać, że wójt może dokonać dekoncentracji swoich kompetencji zarówno stale, jak i czasowo. Taką możliwość daje mu prawo do uregulowania tej kwestii w regulaminie organizacyjnym gminy, regulaminie pracy czy statucie ${ }^{50}$. Dekoncentracja dokonana w akcie wewnętrznym urzędu gminy nosi cechy trwałości i w przypadku zmiany na stanowisku wójta nie pociąga za sobą zmiany zakresu obowiązków sekretarza gminy ${ }^{51}$. Może się to także odbywać przez udzielenie upoważnienia w danej sprawie, $\mathrm{np}$. w postaci pełnomocnictwa do reprezentowania gminy w postępowaniu administracyjnym czy cywilnym ${ }^{52}$. Natomiast przekazanie upoważnienia

${ }^{44}$ B. Dolnicki, Wplyw..., s. 82.

${ }^{45}$ Ibidem, s. 81-82.

${ }^{46}$ Wyrok NSA z dnia 24 września 2015 r., II OSK 176/14; wyrok WSA z Wrocławia z dnia 30 listopada 2012 r., III SA/Wr 487/12, LEX nr 1249750.

${ }^{47}$ C. Martysz, Komentarz do art. 39..., s. 807-808.

${ }^{48}$ A. Rycak, Komentarz do art. 5..., s. 37.

${ }^{49}$ Wyrok NSA z dnia 24 września 2015 r., II OSK 176/14.

${ }^{50}$ Wyrok SN z dnia 3 grudnia 2010 r., I PK 155/10, LEX nr 738397.

${ }^{51}$ Wyrok NSA z dnia 3 grudnia 2008 r., II OSK 1458/08.

${ }^{52}$ Postanowienie SN z dnia 9 lipca 2009 r., III CZP 19/09, LEX nr 512985. 
przez sekretarza gminy na rzecz innej osoby w ramach posiadanych przez niego uprawnień nie jest dopuszczalne ${ }^{53}$.

Podkreśla się, że do zakresu zadań sekretarza gminy powinny należeć przede wszystkim sprawy urzędu gminy, jego organizacja, funkcjonowanie i nadzór nad kierowaną jednostką ${ }^{54}$.

\section{3. Łączenie stanowisk}

Stanowisko sekretarza gminy ma charakter autonomiczny. Zgodnie z postanowieniami ustawy bezpośrednio podlega kierownikowi urzędu, którym jest wójt. Nie można więc łączyć stanowiska wójta ze stanowiskiem sekretarza, musi zajmować je inna osoba ${ }^{55}$. Za taką wykładnią opowiedział się w 2005 r. Wojewódzki Sąd Administracyjny w Białymstoku6 ${ }^{56}$. Zdaniem Sądu wiązało się to bezpośrednio z obowiązującym w poprzednim stanie prawnym obsadzeniem stanowiska sekretarza w drodze powołania i kompetencją wójta w zakresie przedstawiania kandydatów na to stanowisko, wybieranych następnie przez radę gminy. Zgodnie z zasadą nemo est iudex in propria causa nie było możliwe, aby wnioskodawca i powoływany stanowili te same podmioty. Tożsamość tych podmiotów uważana bowiem była za próbę obejścia prawa i nie akceptowano takiego rozwiązania ${ }^{57}$.

Do podobnych wniosków możemy dojść na podstawie obecnej regulacji prawnej. Co prawda nie dochodzi już do powołania sekretarza gminy na wniosek wójta, ale sekretarz jest zatrudniany na podstawie umowy o pracę. Powinno się przeprowadzić w tym celu otwarty i konkurencyjny nabór, co ustawodawca starał się podkreślić, podwajając niejako przepisy ustawowe ${ }^{58}$.

Otwartość i konkurencyjność naboru na stanowisko sekretarza wyłącza możliwość zatrudnienia sekretarza gminy na stanowisku poprzez awans wewnętrzny lub przeniesienie, niezależnie od tego, czy miałoby ono odbyć się w ramach wewnętrznych komórek organizacyjnych urzędu gminy, czy wykraczać na zewnątrz jednostki. Nie ma też możliwości zatrudnienia sekretarza na podstawie innej formy, jak tylko umowa o pracę ${ }^{59}$.

${ }^{53}$ R. Szarek, Glosa..., s. 76-79; postanowienie SN z dnia 9 lipca 2009 r., III CZP $19 / 09$.

${ }^{54}$ Wyrok WSA w Kielcach z dnia 28 września 2010 r., II SA/Ke 368/07, LEX nr 653619.

${ }^{55}$ Wyrok WSA w Białymstoku z dnia 15 marca 2005 r., II SA/Bk 804/04.

${ }^{56}$ Ibidem.

${ }^{57}$ Ibidem.

${ }^{58}$ Brak możliwości powierzenia stanowiska sekretarzowi gminy w inny sposób niż w drodze otwartego i konkurencyjnego naboru wynika z przepisów dotyczących innych pracowników samorządowych - art. 11 ust. 1 u.p.s., a także z przepisów konstytucyjnych - art. 60 Konstytucji RP. Natomiast wprowadzenie nowego przepisu art. 1a i 1b wiązało się z nieprawidłowościami przy obsadzaniu stanowisk w samorządzie gminnym, A. Rycak, Komentarz do art. 5..., s. 39-41.

${ }^{59}$ Ibidem, s. 36, 41. 
Naczelny Sąd Administracyjny oddział zamiejscowy w Poznaniu wyraził pogląd, że można łączyć wykonywanie zadań na stanowisku sekretarza gminy z funkcją zastępcy wójta (burmistrza) ${ }^{60}$. Jedyną przesłanką, która musi być spełniona, jest rozmiar zadań właściwych dla obu stanowisk. Musi on pozwalać na faktyczne wykonywanie zadań przez jedną osobę. NSA nie znajduje tu żadnych przeszkód prawnych. Ponadto podkreśla, że w niewielkich gminach taka praktyka ma również uzasadnienie finansowe ${ }^{61}$. Inaczej na ten temat wypowiada się J. Korczak. Stwierdza, że nie istnieje możliwość łączenia funkcji zastępcy wójta i sekretarza gminy, co wiąże się $\mathrm{z}$ brakiem okresowości zajmowanego przez sekretarza stanowiska. Połączenie tych dwóch stanowisk kłóciłoby się z istotą obu funkcji, a mianowicie zastępstwa wójta, jako „imiennie oznaczonej osoby” i zadań wykonywanych przez sekretarza na rzecz gminy jako jednostki samorządowej ${ }^{62}$.

Zgodnie $\mathrm{z}$ art. $24 \mathrm{f}$ ust. 2 u.s.g. sekretarzem gminy nie może być członek władz zarządzających lub kontrolnych i rewizyjnych. Także pełnomocnik spółek z udziałem gminnych osób prawnych nie może zajmować takiego stanowiska, a zawarcie umowy o pracę na stanowisku sekretarza gminy musi wiązać się z odstąpieniem od wykonywania tej funkcji.

Wykonywanie zadań sekretarza gminy można łączyć z zatrudnieniem na stanowisku kierownika USC, ale zawsze zatrudnienie musi nastąpić na podstawie odrębnych umów. Wynika to z przyjęcia szerokiej interpretacji określonych spraw gminy $z$ art. 33 ust. 4 u.s.g. Sekretarz gminy nie ma ustawowo określonych zadań, może wykonywać te, które leżą w kompetencji wójta. Skoro więc obligatoryjność zatrudnienia innej osoby na stanowisku kierownika USC ma miejsce $w$ gminach powyżej 50 tys. mieszkańców, można stwierdzić, że w zakres zadań kierownika USC wchodzi wykonywanie określonych kompetencji wójta. Realizacja więc tych zadań przez sekretarza gminy jest wykonywaniem uprawnień wójta (powierzonych na mocy art. 33 ust. 4 u.s.g.), a taka sytuacja jest dopuszczalna w świetle obecnych przepisów prawa. Nie kłóci się to także z dyrektywą braku nadmiernego rozszerzenia zadan koniecznych do wykonywania przez jedną osobę łączącą dwie funkcje, którą sformułował NSA oddział zamiejscowy w Poznaniu ${ }^{63}$. Problemem jest natomiast konieczność nawiązania dwóch stosunków pracy z taką osobą, co rodzi komplikacje dotyczące wymiaru czasu pracy ${ }^{64}$. W ramach pełnienia funkcji kierownika USC sekretarz gminy ma obowiązek realizować zadania określone na mocy przepisów usta-

${ }^{60}$ Wyrok NSA w Poznaniu z dnia 27 czerwca 1991 r., SA/Po 1479/90, CBOSA.

${ }^{61}$ Ibidem.

${ }^{62}$ J. Korczak, Zastępstwo organu wykonawczego gminy „,Nowe Zeszyty Samorządowe" 2005 , nr 3, s. 33.

${ }^{63}$ Wyrok NSA oz. w Poznaniu z dnia 27 czerwca 1991 r., SA/Po 1479/90.

${ }^{64}$ M. Grudek, Kierownik USC a zadania sekretarza, http://www.wspolnota.org.pl/ aktualnosci/aktualnosc/kierownik-usc-a-zadania-sekretarza/ (10.11.2017). 
wy z dnia 28 listopada 2014 r. - Prawo o aktach stanu cywilnego ${ }^{65}$, ustawy z dnia 25 lutego 1964 r. - Kodeks rodzinny i opiekuńczy ${ }^{66}$, Kodeksu cywilnego i przepisów wykonawczych do tych ustaw. Może on wydawać oraz podpisywać wszystkie dokumenty, odpisy, decyzje i postanowienia określone w tych przepisach, a także ma obowiązek wydawać zaświadczenia na potwierdzenie zaistniałych stanów faktycznych ${ }^{67}$.

\subsection{Nawiązanie stosunku pracy}

Nawiązanie stosunku pracy z sekretarzem gminy odbywa się na podstawie umowy o pracę zawieranej $\mathrm{z}$ wójtem (burmistrzem, prezydentem miasta) jako reprezentantem pracodawcy ${ }^{68}$. Z wykładni art. 16 u.p.s. wynika, że może ona zostać nawiązana na czas określony lub nieokreślony. Nigdy nie może być zawarta na czas pełnienia funkcji przez wójta. W taki sposób mogli być zatrudniani tylko doradcy i asystenci. Inne formy cywilnoprawne zawierania stosunku pracy z sekretarzem gminy są niedopuszczalne (umowa o dzieło, umowa zlecenie). Artykuł 5 ust. 1b u.p.s. explicite zakazuje powierzania stanowiska sekretarzowi, nawet na okres do trzech miesięcy, zgodnie z art. 21 u.p.s. Na mocy tego artykułu nie może on wykonywać innej pracy niż ta określona w umowie o pracę, nawet jeżeli byłaby zgodna z jego kwalifikacjami. Obsadzenie stanowiska nigdy nie może więc nastąpić przez powierzenie obowiązków ${ }^{69}$. Warto dodać, że nawiązywanie stosunku pracy w drodze umowy o pracę jest najbardziej uniwersalnym i powszechnym sposobem ${ }^{70}$. Zatrudnienie na stanowisku sekretarza na czas określony jest możliwe tylko w przypadku kiedy dochodzi do usprawiedliwionej nieobecności w pracy sekretarza, na czas tej nieobecności. Nie ma tutaj zastosowania art. 16 ust. 2 u.p.s. ze względu na wymogi formalne, które musi spełnić osoba ubiegająca się o stanowisko sekretarza w kontekście legalnej definicji osoby podejmującej po raz pierwszy pracę. M. Rotkiewicz wyraża pogląd, że dopuszczalne jest obsadzenie stanowiska sekretarza w drodze awansu pracownika samorządowego zajmującego stanowisko urzędnicze, ale tylko w obrębie „tej samej grupy stanowisk”, dokonujące się przez przeniesienie ${ }^{71}$.

${ }^{65}$ Tekst jedn.: Dz.U. z 2016 r. poz. 2064 ze zm.

${ }^{66}$ Tekst jedn.: Dz.U. z 2017 r. poz. 682 ze zm.

${ }^{67}$ Upoważnienie z dnia 12 grudnia 2014 r. Zastępca Kierownika Urzędu Stanu Cywilnego Og.SO 0052.14.2014, gmina Maków Podhalański.

${ }^{68} \mathrm{~K}$. Kawecki [w:] Ustawa o pracownikach samorzadowych. Komentarz ze wzorami regulaminów, zarządzeń i uchwał, K. Kawecki, S. Płażek (red.), Warszawa 2009, s. 17.

${ }^{69}$ M. Rotkiewicz, Komentarz do art. 5..., s. 15.

${ }^{70}$ J. Stelina, Komentarz do art. 4..., s. 34.

${ }^{71}$ M. Rotkiewicz, Komentarz do art. 5..., s. 15. 


\subsection{Apolityczność a apartyjność}

Znowelizowany art. 5 ust. 5 u.p.s. stanowi, że sekretarz nie może tworzyć i przynależeć do partii politycznych. Oczywiście dotyczy to także sekretarza gminy. Należy jednak zwrócić uwagę, że sekretarz gminy nie ma obowiązku pozostawania apolitycznym, a wyłącznie apartyjnym. Neutralność polityczna oznacza „zakaz publicznego manifestowania poglądów politycznych i zakaz kierowania się przy wykonywaniu obowiązków służbowych własnymi przekonaniami politycznymi"72. Apolityczność ma więc szerszy zakres niż apartyjność i podnoszona jest do rangi zasady prawnej. Natomiast apartyjność wyrażona jest wprost w przepisach ustawowych i możemy utożsamiać ją z bezpartyjnością. Sekretarz gminy może więc angażować się w działalność polityczną, być radnym, uczestniczyć w kampanii wyborczej czy popierać konkretną partię polityczną ${ }^{73}$. Nie jest także zakazane, by sekretarz gminy należał do związku zawodowego, zrzeszenia czy organizacji krajowej bądź zagranicznej ${ }^{74}$. Jednak musi to czynić w sposób odpowiedni. Taka działalność nie może prowadzić do podejmowania czynności, które będą pozostawały w sprzeczności z jego obowiązkami lub powodowały „uzasadnione podejrzenie o stronniczość lub interesowność”75. Natomiast w uzasadnieniu do projektu ustawy o pracownikach samorządowych podkreśla się konieczność pozostawania przez sekretarza gminy apolitycznym, łącząc wymóg apartyjności z klauzulą bezstronności przewidzianą w art. 1 u.p.s.: „Preambuła nie zawiera wprost wymogu neutralności politycznej, zawiera jednak wymóg bezstronności, który oznacza niezależność od wszelkich wpływów"76. Wydaje się jednak błędne posłużenie się w uzasadnieniu pojęciem apolityczności w kontekście art. 5 ust. 5 u.p.s. Bowiem jak to wyżej wspomniano, tworzenie i przynależenie do partii politycznych nie wymaga całkowitego odsunięcia się od szeroko pojmowanej działalności politycznej, a ustawodawcy chodziło tylko o wprowadzenie bezwzględnej apartyjności, popartej bezstronnym wykonywaniem powierzonych zadań, nie zaś całkowitej apolityczności.

Jeżeli sekretarz gminy przed zawarciem stosunku pracy z urzędem gminy należał do partii politycznej, niezwłocznie musi z niej wystąpić. Ostateczny termin nie upływa $z$ chwilą podpisania umowy, a z momentem przystąpienia do wykonywania obowiązków ${ }^{77}$.

${ }^{72}$ Wyrok TK z dnia 10 kwietnia 2002 r., K 26/00, http://ipo.trybunal.gov.pl/ipo/ Sprawa? cid=1\&dokument=389\&sprawa=2765 (8.12.2017).

${ }^{73}$ B. Skóbel, Okiem prawnika. Sekretarz gminy lub powiatu musi być apartyjny, a nie apolityczny, http://wartowiedziec.org/index.php/start/felietony/12743-sekretarz-apartyjny-a-nie-apolityczny (10.11.2017).

${ }^{74}$ A. Szewc, T. Szewc, Komentarz do art. 5..., s. 99.

${ }^{75}$ M. Rotkiewicz, Komentarz do art. 5..., s. 16.

${ }^{76}$ Druk nr 725 Sejmu RP VI kadencji z dnia 7 lipca 2008 r., Warszawa, s. 4-6, http:// ww2.senat.pl/k7/dok/sejm/021/752.pdf (29.06.2018).

${ }^{77}$ A. Szewc, T. Szewc, Komentarz do art. 5..., s. 99. 


\section{Rodzaje zadań sekretarza gminy}

Ustawodawca zrezygnował z dokładnego sprecyzowania zadań sekretarza w aktach prawnych powszechnie obowiązujących, a katalog kompetencji wójta, które mogą zostać przeniesione na rzecz sekretarza gminy, nie jest zamknięty. W związku z szeroką interpretacją „określonych spraw gminy” $\mathrm{z}$ art. 33 ust. 4 u.s.g. w praktyce często dochodzi do powierzenia wykonywania faktycznej funkcji kierownika urzędu gminy właśnie sekretarzowi ${ }^{78}$, co oczywiście nie pozbawia wójta zwierzchnictwa nad prawidłowym wykonywaniem tej funkcji. Warto dodać, że w związku z tzw. władztwem organizacyjnym samorządu organizacja urzędów gminy może być kształtowana w sposób swobodny przez poszczególne gminy ${ }^{79}$, dlatego zakres zadań powierzanych sekretarzowi w danej gminie często jest różny.

\subsection{Zadania dyrektora urzędu}

Najwięcej zadań sekretarz gminy wykonuje jako swoisty dyrektor urzędu gminy. To sekretarz ma zapewniać „funkcjonowanie urzędu jako systemu wzajemnych zależności, powiązań i przepływu informacjii" ${ }^{\prime 0}$. Szeroki zakres tych zadań wynika $\mathrm{z}$ usytuowania sekretarza w strukturze organizacyjnej urzędu gminy na czele komórki organizacyjnej zwanej zazwyczaj referatem organizacyjnym lub referatem do spraw ogólnych i obywatelskich, nad której działalnością sprawuje nadzór ${ }^{81}$. Do zadań tych komórek należy zapewnienie sprawnego funkcjonowania urzędu gminy, jak i organizacja pracy urzędu. To sekretarz gminy opracowuje zakresy czynności zarówno dla osób stojących na czele komórek organizacyjnych urzędu, jak i dyrektorów czy kierowników jednostek organizacyjnych gminy. Do jego zadań należy całość spraw kadrowych urzędu gminy. Jest zwierzchnikiem służbowym pracowników bezpośrednio mu podległych, nadzoruje proces ich doskonalenia zawodowego, kieruje na wyjazdy służbowe, ma prawo wydawać polecenia, czuwa nad przestrzeganiem dyscypliny pracy, rozstrzyga spory kompetencyjne między pracownikami, nadzoruje stosowanie przepisów zawartych w instrukcji kancelaryjnej, koordynuje pracę praktykantów i stażystów, prowadzi współpracę z Powiatowymi Urzędami Pracy i sądami w zakresie zatrudniania osób skierowanych do prac interwencyjnych, prac publicznych i w ramach stażu. Koordynuje sprawy socjalno-bytowe i pracownicze, takie jak podpisywanie delegacji służbowych, szkoleń i urlopów. Ponadto sekretarz ma obowiązek dokonywać okresowych ocen kwa-

${ }^{78}$ B. Dolnicki, Samorzad terytorialny, Warszawa 2016, s. 111.

${ }^{79}$ B. Dolnicki, Samorząd terytorialny, Warszawa 2009, s. 92.

${ }^{80}$ Regulamin organizacyjny Urzędu Gminy Budzów.

${ }^{81}$ Załącznik do regulaminu organizacyjnego Urzędu Gminy w Zembrzycach wprowadzonego zarządzeniem z dnia 30 czerwca 2015 r. Wójta Gminy Zembrzyce nr $89 / 2015$ r. 
lifikacyjnych pracowników i wykonuje czynności z zakresu prawa pracy na rzecz wójta, $\mathrm{z}$ wyjątkiem nawiązywania i rozwiązywania stosunku pracy oraz ustalania wynagrodzenia. Sekretarz gminy jest także właściwy do prowadzenia różnego rodzaju rejestrów (upoważnień, pełnomocnictw, aktów prawnych wydawanych przez organ wykonawczy gminy, instytucji kultury) i książek kontroli ${ }^{82}$. Ogólnie należy zaznaczyć, że sekretarz gminy sprawuje szeroko pojętą kontrolę wewnętrzną w urzędzie gminy ${ }^{83}$.

\subsection{Zadania w zakresie zabezpieczenia prawidłowej działalności organów gminy}

Sekretarz gminy jako osoba wykonująca swoją pracę w sposób niekadencyjny zapewnia swego rodzaju ciągłość w prawidłowym wykonywaniu swoich obowiązków przez organy gminy. W zakresie tej funkcji sekretarz sprawuje nadzór nad opracowywaniem projektów uchwał rady gminy i zarządzeń wójta. Nadzoruje przygotowywanie materiałów na sesje rady gminy oraz posiedzenia komisji rady gminy. Do jego zadań należy także organizacja współpracy z jednostkami organizacyjnymi gminy oraz sołectwami. Ponadto właściwą pracę organów gminy ma zapewnić kontrola korespondencji elektronicznej i listowej oraz przedstawianie jej organowi wykonawczemu. Sekretarz powinien koordynować i zachowywać ciągłość współpracy w związkach i porozumieniach międzygminnych. W gestii sekretarza pozostawia się także opracowywanie projektów statutu gminy. Najważniejszym jednak zadaniem $\mathrm{z}$ tego zakresu złożonym na braki sekretarza jest sprawowanie kontroli zarządczej. Ma ona na celu podejmowanie takich działań, które doprowadzą do zgodnej z prawem, efektywnej, oszczędnej i terminowej realizacji celów i zadań gminy ${ }^{84}$.

\subsection{Zadania wynikające z zastępstwa wójta}

Praktyka pokazuje, że zadania powierzane na mocy upoważnień, jak i te nadane przez regulaminy dają sekretarzowi gminy szerokie uprawnienia do wykonywania zadań w ramach zastępstwa wójta w czasie jego nieobecności lub niemożności wykonywania obowiązków. Sekretarz gminy otrzymuje

${ }^{82}$ Upoważnienie z dnia 12 grudnia 2014 r. Sekretarz Gminy-Kierownik referatu Ogólnego i Spraw Obywatelskich nr Og.SO 0052.14.2014, gmina Maków Podhalański; regulamin organizacyjny Urzędu Gminy Maków Podhalański; zarządzenie z dnia 30 czerwca 2015 r. nr 89/2015 Wójta Gminy Zembrzyce w sprawie: regulaminu organizacyjnego Urzędu Gminy Zembrzyce; regulamin organizacyjny Urzędu Gminy Budzów; zarządzenie z dnia 1 grudnia 2015 r. nr 80/2015 Wójta Gminy Budzów w sprawie: upoważnienia i powierzenia spraw sekretarzowi gminy.

${ }^{83}$ Z. Leoński, Samorząd..., s. 131.

${ }^{84}$ Zarządzenie z dnia 30 czerwca 2015 r. nr 89/2015 Wójta Gminy Zembrzyce w sprawie: regulaminu organizacyjnego Urzędu Gminy Zembrzyce; regulamin organizacyjny Urzędu Gminy Budzów; zarządzenie z dnia 31 grudnia 2015 r. nr 93/2015 Wójta Gminy Budzów w sprawie: zmiany regulaminu organizacyjnego Urzędu Gminy w Budzowie. 
możliwość podpisywania, czyli nadania mocy prawnie wiążącej wszelkiego rodzaju dokumentom, w tym dokumentom finansowym i związanym z zarządem mieniem gminy, decyzjom, postanowieniom, zaświadczeniom oraz innym pismom pozostającym w zakresie kompetencji wójta. W gestii sekretarzy gminy są także zadania wynikające z prowadzenia spraw wykorzystujących środki pochodzące $\mathrm{z}$ funduszy europejskich i krajowych ${ }^{85}$.

\subsection{Zadania samoistne}

Samoistnym, niezależnym od postanowień regulaminów gminnych i upoważnień wójta, wynikającym wprost z przepisów prawa uprawnieniem sekretarza gminy jest ustne przyjęcie ostatniej woli spadkodawcy w obecności jeszcze co najmniej dwóch świadków (art. 951 k.c.). Historia tego uprawnienia sięga instytucji sekretarza prezydium rady narodowej. Natomiast obecnie rękojmię prawidłowego wykonywania tego zadania przez sekretarza gminy zapewnia wymóg posiadania wyższego wykształcenia i odpowiedniego stażu pracy przez kandydata na to stanowisko. Przeszkodą do wiążącego sporządzenia testamentu alograficznego jest skazanie sekretarza za fałszywe zeznania ${ }^{86}$.

\subsection{Zadania zabezpieczająco-koordynacyjne}

W ramach uprawnień zabezpieczająco-koordynacyjnych sekretarz gminy zapewnia prawidłowe prowadzenie dokumentacji zawierającej informacje niejawne. To zadanie bezpośrednio koresponduje $z$ etymologią pojęcia „sekretarz”, oznaczającego w języku łacińskim tego, któremu można zawierzyć tajemnicę ${ }^{87}$. Ponadto zapewnia realizację planów operacyjnych w przypadku powodzi lub stanów klęsk żywiołowych, ubezpieczenie mienia komunalnego, a także prawidłową realizację przepisów o zamówieniach publicznych i koordynację informatyzacji administracji gminnej. Sekretarz pełni w niektórych gminach funkcję rzecznika prasowego, który ma trzymać pieczę nad informacjami zamieszczanymi w środkach masowego przekazu i odpowiadać na krytykę działalności organów gminy. Do zadań koordynacyjnych można zaliczyć także zarząd budynkiem, sprzętem i pomieszczeniami urzędu gminy ${ }^{88}$.

${ }^{85}$ Upoważnienie z dnia 12 grudnia 2014 r. sekretarz gminy-kierownik Referatu Ogólnego i Spraw Obywatelskich nr Og.SO 0052.14.2014, gmina Maków Podhalański; regulamin organizacyjny Urzędu Gminy Maków Podhalański; pełnomocnictwo z dnia 29 marca 2017 r. nr Og.SO 0052.3.2017, gmina Maków Podhalański; regulamin organizacyjny Urzędu Gminy Budzów; zarządzenie z dnia 1 grudnia 2015 r. nr 80/2015 Wójta Gminy Budzów w sprawie: upoważnienia i powierzenia spraw sekretarzowi gminy.

${ }^{86}$ A. Wierzbica, Pozycja ustrojowa sekretarza..., s. 42-43.

${ }^{87}$ Ibidem, s. 29.

${ }^{88}$ Regulamin organizacyjny Urzędu Gminy Budzów; regulamin organizacyjny Urzędu Gminy Zembrzyce. 


\subsection{Zadania w zakresie czynności zwykłego zarządu}

W ramach czynności bieżącego załatwiania spraw gminy sekretarze otrzymują prawo do jednoosobowego składania oświadczeń woli zarówno w sprawach publiczno-, jak i prywatnoprawnych. Mają także prawo do reprezentowania gmin na zewnątrz przed sądami i innymi organami administracji publicznej oraz dysponują ogólnym pełnomocnictwem procesowym i pełnomocnictwem do zawierania umów cywilnoprawnych. Dzięki posiadanym upoważnieniom mogą realizować projekty dotyczące społecznych i gospodarczych inwestycji na terenie gminy, występować o dofinansowanie tych projektów do odpowiednich organów, składać odwołania, wyjaśnienia i zmiany do złożonych wniosków ${ }^{89}$.

\subsection{Zadania w ramach służby publicznej}

Zadania sekretarza gminy nie ograniczają jego pracy do formalnych spraw urzędu. Dzięki szerokiemu rozumieniu spraw gminy sekretarz wychodzi poza struktury i świadczy służbę na rzecz obywatela. Do zadań z tego zakresu należy przede wszystkim wydawanie w imieniu wójta decyzji w indywidualnych sprawach z zakresu administracji publicznej. Ze względu na podstawę prawną tego rozstrzygnięcia możemy wyróżnić dwa typy tych decyzji: regulaminowe, czyli wydawane w zakresie wszystkich spraw przyznanych sekretarzowi gminy przez regulamin organizacyjny, oraz upełnomocnione, czyli te wydane na podstawie pisemnego upoważnienia w konkretnej sprawie. Ważnym zadaniem sekretarza gminy pełnionym $\mathrm{w}$ ramach służby publicznej jest realizacja organizacji i załatwienia skarg. Sekretarz w tym zakresie nie tylko czuwa nad terminowym załatwianiem skarg i wniosków, ale także prowadzi rejestry, przyjmuje i osobiście rozpatruje skargi i wnioski. Powierza się mu także dokonywanie analizy przyczyn wnoszenia skarg i wniosków oraz przedstawianie ich wójtowi. Ponadto sekretarz gminy ma obowiązek poświadczać własnoręczność podpisu (zarówno na podstawie ustawy z dnia 14 lutego $1991 \mathrm{r}$. - Prawo o notariacie $e^{90}$, jak i ustawy z dnia 17 grudnia 1998 r. o emeryturach i rentach z Funduszu Ubezpieczeń Społecznych ${ }^{91}$ oraz przepisów dotyczących zaopatrzenia emerytalnego funk-

${ }^{89}$ Zarządzenie z dnia 25 lipca 2017 r. nr 74/2017 Wójta Gminy Zembrzyce w sprawie udzielenia pełnomocnictwa sekretarzowi gminy Zembrzyce; zarządzenie $\mathrm{z}$ dnia 25 lipca 2017 r. nr 75/2017 w sprawie: udzielenia pełnomocnictwa w zakresie realizacji projektu pod nazwą „Budowa Centrum Rekreacji i Wypoczynku nad potokiem Paleczka w Zembrzycach"; zarządzenie z dnia 25 lipca 2017 r. nr 77/2017 Wójta Gminy Zembrzyce $\mathrm{w}$ sprawie: udzielenia pełnomocnictwa $\mathrm{w}$ zakresie realizacji projektu pod nazwą „Rozbudowa kanalizacji sanitarnej w miejscowości Tarnawa Dolna”; zarządzenie z dnia 1 grudnia 2015 r. nr 80/2015 Wójta Gminy Budzów w sprawie: upoważnienia i powierzenia spraw sekretarzowi gminy.

${ }^{90}$ Tekst jedn.: Dz.U. z 2017 r. poz. 2291 ze zm.

${ }^{91}$ Tekst jedn.: Dz.U. z 2018 r. poz. 1270 ze zm. 
cjonariuszy Policji, ABW, AW, Straży Granicznej, BOR i PSP). Może też uwierzytelniać kopie dokumentów i stwierdzać ich zgodność z oryginałem. Sekretarze czuwają nad terminowym i rzetelnym załatwieniem spraw obywateli. To im powierzony zostaje nadzór nad przeprowadzaniem wyborów (do Sejmu i Senatu, Prezydenta RP, do rady gminy, wójta, referendów krajowych i gminnych) i prawidłową realizacją ustawy o dostępie do informacji publicznej. Na sekretarzach ciąży również obowiązek zamieszczania i aktualizacji informacji w Biuletynie Informacji Publicznej ${ }^{92}$.

\section{Podsumowanie}

Sekretarz gminy jest przede wszystkim pomocnikiem wójta, który ma ułatwiać kierowanie całokształtem działalności urzędu gminy. Praktyka, wskazując na rangę instytucji, sytuuje sekretarza w obrębie kierownictwa urzędu zaraz po wójcie, podkreślając, że pełni on funkcje kierownika administracyjnego urzędu gminy ${ }^{93}$.

Spośród wszystkich trzech samorządów w Polsce rola i pozycja sekretarza jest szczególnie istotna właśnie $\mathrm{w}$ gminie. Wynika to $\mathrm{z}$ faktu, że tylko $\mathrm{w}$ gminie organizacja pracy urzędu spoczywa w rękach monokratycznego organu wykonawczego - wójta. Zarówno w powiecie, jak i w województwie dokonuje się ona za zgodą organów kolegialnych ${ }^{94}$ (zarząd powiatu i zarząd województwa).

W literaturze ${ }^{95}$ podkreśla się, że ustawodawca, kreując instytucję sekretarza gminy, dopuścił się swoistej niekonsekwencji. Z jednej strony wyodrębniając to stanowisko spośród innych pracowników samorządowych, wydzielając osobny art. 5 u.p.s. dotyczący sekretarza i podnosząc niejako jego rangę rangą do zastępcy kierownika urzędu (a zarazem organu administracji) na mocy art. 33 ust. 4 u.s.g., chciał ustanowić go pierwszym, najważniejszym pracownikiem, swoistą "głową zespołu”. Natomiast z drugiej strony ustawodawca umniejsza rolę sekretarza i nie pozwala traktować go jako specjalnego, podlegającego szczególnemu reżimowi prawnemu pra-

${ }^{92}$ Upoważnienie z dnia 16 października 2013 r. Sekretarza Gminy-Kierownika ref.Og.SO nr Og.SO 0052.8.2013, gmina Maków Podhalański; upoważnienie z dnia 12 grudnia 2014 r. Sekretarz Gminy-Kierownik referatu Ogólnego i Spraw Obywatelskich nr Og.SO 0052.14.2014, gmina Maków Podhalański; regulamin organizacyjny Urzędu Gminy Maków Podhalański; zarządzenie z dnia 30 czerwca 2015 r. nr 89/2015 Wójta Gminy Zembrzyce w sprawie: regulaminu organizacyjnego Urzędu Gminy Zembrzyce; regulamin organizacyjny Urzędu Gminy Budzów; zarządzenie z dnia 1 grudnia 2015 r. nr 80/2015 Wójta Gminy Budzów w sprawie: upoważnienia i powierzenia spraw sekretarzowi gminy.

${ }^{93}$ Regulamin organizacyjny Urzędu Gminy Budzów; zarządzenie z dnia 31 grudnia 2015 r. nr 93/2015 Wójta Gminy Budzów w sprawie: zmiany regulaminu organizacyjnego Urzędu Gminy w Budzowie.

${ }^{94}$ P. Groński, Komentarz do art. 5..., s. 66.

${ }^{95}$ K. Kawecki, Ustawa..., s. 21; A. Szewc, T. Szewc, Komentarz do art. 5..., s. 93. 
cownika urzędu przez zrównanie w sposobie zawierania stosunku pracy $\mathrm{w}$ postaci umowy o pracę. Prawodawca zrezygnował więc z możliwości nadania szczególnego statusu primus inter pares sekretarzowi przez możliwość zawarcia z nim stosunku pracy w drodze wyboru, mianowania czy powołania. Na mocy poprzedniej regulacji ustawowej sekretarz gminy był powoływany na stanowisko, natomiast w wyniku noweli z 2008 r. stracił to prawo na rzecz umowy o pracę. Jak podkreśla się w doktrynie, nawiązanie stosunku pracy na podstawie umowy o pracę miało mieć miejsce w stosunku do osób, które usytuowane są w hierarchii służbowej pracowników samorządowych szczególnie nisko, przede wszystkim w roli pomocników i asystentów ${ }^{96}$.

Jednak warto zwrócić uwagę, że powołanie wiąże się także z możliwości odwołania osoby tak zatrudnionej w każdej chwili przez powołujący organ. Dlatego związanie stosunkiem pracy jest słabe, nietrwałe ${ }^{97}$. Natomiast rezygnacja $\mathrm{z}$ takiego rozwiązania $\mathrm{z}$ jednej strony osłabia współpracę, $\mathrm{z}$ drugiej pozwala na większą swobodę pracownika i korzystanie z wiedzy i doświadczenia zawodowego $\mathrm{w}$ wykonywaniu powierzonych przez wójta zadań.

Sekretarz gminy jest urzędnikiem samorządowym sensu stricto, co oznacza, że bezwzględnie należy stosować w stosunku do zajmowanego przez niego stanowiska przepisy „prawa urzędniczego”, czyli ustawy o pracownikach samorządowych ${ }^{98}$. Wiąże się to z niemożnością pominięcia przy zatrudnianiu na stanowisko sekretarza obowiązku przeprowadzenia otwartego i konkurencyjnego naboru.

Mimo że ustawa o samorządzie gminnym normuje tylko w sposób lakoniczny ${ }^{99}$ wykonywanie funkcji przez sekretarza gminy, to rola i złożone na jego barkach zadania są ogromne. Orzecznictwo podkreśla, że sekretarz gminy wykonuje swoje zadania w oparciu o ścisłą współpracę z wójtem ${ }^{100}$. „Szczególna pozycja jaką zajmuje sekretarz w strukturze organizacyjnej gminy sprawia, że charakter relacji między nim a wójtem jest szczególny. Relacje zawodowe między wójtem a sekretarzem gminy muszą opierać się $\mathrm{w}$ dużej mierze na zaufaniu. Brak tego zaufania może destabilizować pracę urzędu gminy" 101 .

Można rzec, że sekretarz gminy pełni swoistą rolę quasi-organu. Nie ma co prawda samoistnych kompetencji, które przysługują organowi administrującemu, ale rozbudowany katalog zadań w praktyce ukazuje, że dekoncentracja "kompetencji organu” jest szeroka i ma mocne umocowanie w aktach prawnych i upoważnieniach.

${ }^{96}$ M. Taniewska-Peszko, Stosunki pracy $w$ samorzadzie terytorialnym [w:] Zarys prawa samorządu terytorialnego, A. Agopszowicza, Z. Gilowskiej, M. Taniewskiej-Peszko (red.), Katowice 1997, s. 200.

${ }^{97}$ J. Stelina, Komentarz do art. 5..., s. 33.

${ }_{98}$ Idem, Prawo urzędnicze, Warszawa 2017, s. 104.

${ }^{99}$ Z. Leoński, Samorząd..., s. 130.

${ }^{100}$ Wyrok WSA w Białymstoku z dnia 15 marca 2015 r., SA/Bk 804/04.

${ }^{101}$ Wyrok NSA z dnia 19 czerwca 2012 r., II OSK 870/12, CBOSA. 


\section{Bibliografia}

Augustyniak M., Samorząd terytorialny [w:] Prawo administracyjne, M. Zdyb, J. Stelmasiak (red.), Warszawa 2016.

Budzisz R., Komentarz do art. 33 [w:] Ustawa o samorządzie gminnym. Komentarz, P. Chmielnicki (red.), Warszawa 2013.

Dolnicki B., Samorząd terytorialny, Warszawa 2016.

Dolnicki B., Samorzad terytorialny, Warszawa 2009.

Dolnicki B., Wpływ nowych zasad wyboru wójta (burmistrza, prezydenta miasta) na relacje z rada gminy, „Przegląd Prawa Publicznego” 2007, nr 1-2.

Groński P., Ustawa z dnia 21 listopada 2008 r. o pracownikach samorzadowych (Dz. U. Nr 223, poz. 1458). Komentarz, Warszawa 2010.

Grudek M., Kierownik USC a zadania sekretarza, http://www.wspolnota.org.pl/aktualnosci/aktualnosc/kierownik-usc-a-zadania-sekretarza/.

Korczak J., Zastępstwo organu wykonawczego gminy, „Nowe Zeszyty Samorządowe" 2005, nr 3.

Leoński Z., Samorząd terytorialny w RP, Warszawa 2006.

Lewicki M., Cudzoziemcy [w:] Materialne prawo administracyjne. Pojęcia, instytucje, zasady, M. Stahl (red.), Warszawa 2002.

Martysz C., Komentarz do art. 33 [w:] Ustawa o samorzadzie gminnym. Komentarz, B. Dolnicki (red.), Warszawa 2016.

Rotkiewicz M., Ustawa o pracownikach samorzadowych. Komentarz, Warszawa 2016.

Ruczkowski P., Obywatelstwo polskie [w:] Prawo administracyjne, M. Zdyb, J. Stelmasiak (red.), Warszawa 2016.

Rycak A., Rycak M., Stelina J., Ustawa o pracownikach samorzadowych. Komentarz, Warszawa 2016.

Skóbel B., Okiem prawnika. Sekretarz gminy lub powiatu musi być apartyjny, a nie apolityczny, http://wartowiedziec.org/index.php/start/felietony/12743-sekretarz-apartyjny-a-nie-apolityczny.

Stelina J., Prawo urzędnicze, Warszawa 2017.

Szarek R., Glosa do postanowienia SN z dnia 9 lipca 2009 r., III CZP 19/09, „Samorząd Terytorialny" 2010, nr 9, s. 76-79.

Szewc A., Szewc T., Komentarz do art. 5 [w:] Ustawa o pracownikach samorzadowych. Komentarz, A. Szewc (red.), Warszawa 2011.

Taniewska-Peszko M., Stosunki pracy w samorzadzie terytorialnym [w:] Zarys prawa samorzadu terytorialnego, A. Agopszowicza, Z. Gilowskiej, M. Taniewskiej-Peszko (red.), Katowice 1997.

Ustawa o pracownikach samorzadowych. Komentarz, M. Rycak, A. Rycak, J. Stelina (red.), Warszawa 2016.

Ustawa o pracownikach samorzadowych. Komentarz ze wzorami regulaminów, zarządzeń i uchwał, K. Kawecki, S. Płażek (red.), Warszawa 2009.

Wierzbica A., Pozycja ustrojowa sekretarza jednostki samorzadu terytorialnego, „Studia Prawno-Ekonomiczne” 2009, t. LXXIX. 


\section{Akty prawne i dokumenty urzędowe}

Traktat o funkcjonowaniu Unii Europejskiej, Dz.Urz. UE z 2016 r. C 202, s. 47.

Ustawa z dnia 25 lutego 1964 r. - Kodeks rodzinny i opiekuńczy, tekst jedn.: Dz.U. z 2017 r. poz. 682 ze zm.

Ustawa z dnia 23 kwietnia 1964 r. - Kodeks cywilny, tekst jedn.: Dz.U. z 2018 r. poz. $1025 \mathrm{ze}$ zm.

Ustawa z dnia 26 czerwca 1974 r. - Kodeks pracy, tekst jedn.: Dz.U. z 2018 r. poz. $917 \mathrm{ze} \mathrm{zm}$.

Ustawa z dnia 8 marca 1990 r. o samorządzie gminnym, tekst jedn.: Dz.U. z 2018 r. poz. 994 ze zm.

Ustawa z dnia 22 marca 1990 r. o pracownikach samorządowych, tekst jedn.: Dz.U. z 2018 r. poz. 1260 ze zm.

Ustawa z dnia 14 lutego 1991 r. - Prawo o notariacie, tekst jedn.: Dz.U. z 2017 r. poz. $2291 \mathrm{ze} \mathrm{zm}$.

Ustawa z dnia 6 czerwca 1997 r. - Kodeks karny, tekst jedn.: Dz.U. z 2018 r. poz. 2204 ze zm.

Ustawa z dnia 17 grudnia 1998 r. o emeryturach i rentach z Funduszu Ubezpieczeń Społecznych, tekst jedn.: Dz.U. z 2018 r. poz. 1270 ze zm.

Ustawa $\mathrm{z}$ dnia 6 września 2001 r. o dostępie do informacji publicznej, tekst jedn.: Dz.U. z 2018 r. poz. 1330 ze zm.

Ustawa z dnia 27 lipca 2005 r. - Prawo o szkolnictwie wyższym, tekst jedn.: Dz.U. z 2017 r. poz. 2183 ze zm.

Ustawa z dnia 21 listopada 2008 r. o pracownikach samorządowych, tekst jedn.: Dz.U. z 2018 r. poz. 1260 ze zm.

Ustawa z dnia 27 sierpnia 2009 r. o finansach publicznych, tekst jedn.: Dz.U. z 2017 r. poz. 2077 ze zm.

Ustawa z dnia 12 grudnia 2013 r. o cudzoziemcach, tekst jedn.: Dz.U. z 2018 r. poz. $2206 \mathrm{ze} \mathrm{zm}$.

Ustawa z dnia 28 listopada 2014 r. - Prawo o aktach stanu cywilnego, tekst jedn.: Dz.U. z 2016 r. poz. 2064 ze zm.

Druk nr 725 Sejmu RP VI kadencji z dnia 7 lipca 2008 r., Warszawa, http://ww2. senat.pl/k7/dok/sejm/021/752.pdf (29.06.2018).

Regulamin organizacyjny Urzędu Gminy Budzów.

Regulamin organizacyjny Urzędu Gminy Maków Podhalański.

Regulamin organizacyjny Urzędu Gminy Zembrzyce.

Zarządzenie z dnia 25 lipca 2017 r. nr 77/2017 Wójta Gminy Zembrzyce w sprawie: udzielenia pełnomocnictwa w zakresie realizacji projektu pod nazwą „Rozbudowa kanalizacji sanitarnej w miejscowości Tarnawa Dolna”.

Zarządzenie z dnia 25 lipca 2017 r. nr 75/2017 w sprawie: udzielenia pełnomocnictwa w zakresie realizacji projektu pod nazwą „Budowa Centrum Rekreacji i Wypoczynku nad potokiem Paleczka w Zembrzycach”.

Zarządzenie z dnia 25 lipca 2017 r. nr 74/2017 Wójta Gminy Zembrzyce w sprawie udzielenia pełnomocnictwa sekretarzowi gminy Zembrzyce.

Pełnomocnictwo z dnia 29 marca 2017 r. nr Og.SO 0052.3.2017, gmina Maków Podhalański. 
Zarządzenie z dnia 31 grudnia 2015 r. nr 93/2015 Wójta Gminy Budzów w sprawie: zmiany regulaminu organizacyjnego Urzędu Gminy w Budzowie.

Zarządzenie z dnia 1 grudnia 2015 r. nr 80/2015 Wójta Gminy Budzów w sprawie: upoważnienia i powierzenia spraw sekretarzowi gminy.

Zarządzenie z dnia 30 czerwca 2015 r. nr 89/2015 Wójta Gminy Zembrzyce w sprawie: regulaminu organizacyjnego Urzędu Gminy Zembrzyce.

Załącznik do regulaminu organizacyjnego Urzędu Gminy w Zembrzycach wprowadzonego Zarządzeniem z dnia 30 czerwca 2015 r. Wójta Gminy Zembrzyce nr 89/2015 r.

Upoważnienie z dnia 12 grudnia 2014 r. sekretarz gminy-kierownik Referatu Ogólnego i Spraw Obywatelskich nr Og.SO 0052.14.2014, gmina Maków Podhalański.

Upoważnienie z dnia 12 grudnia 2014 r. Zastępca Kierownika Urzędu Stanu Cywilnego Og.SO 0052.14.2014, gmina Maków Podhalański.

Upoważnienie z dnia 16 października 2013 r. sekretarza gminy-kierownika ref.Og. SO nr Og.SO 0052.8.2013, gmina Maków Podhalański.

\section{Orzecznictwo}

Wyrok TK z dnia 10 kwietnia 2002 r., K 26/00, http://ipo.trybunal.gov.pl/ipo/Sprawa? cid=1\&dokument $=389$ \&sprawa $=2765$.

Wyrok NSA w Poznaniu z dnia 27 czerwca 1991 r., SA/Po 1479/90, CBOSA.

Wyrok NSA z dnia 3 grudnia 2008 r., II OSK 1458/08, CBOSA.

Wyrok NSA z dnia 24 kwietnia 2002 r., II SA 2092/01, LEX nr 81800.

Wyrok NSA z dnia 19 czerwca 2012 r., II OSK 870/12, CBOSA.

Wyrok NSA z dnia 24 września 2015 r., II OSK 176/14, LEX nr 1987059.

Postanowienie SN z dnia 9 lipca 2009 r., III CZP 19/09, LEX nr 512985.

Wyrok SN z dnia 16 października 2009 r., I PK 85/09, http://www.sn.pl/sites/ orzecznictwo/orzeczenia1/i\%20pk\%2085-09-1.pdf.

Wyrok SN z dnia 3 grudnia 2010 r., I PK 155/10, LEX nr 738397.

Wyrok WSA w Kielcach z dnia 28 września 2010 r., II SA/Ke 368/07, LEX nr 653619.

Wyrok WSA w Białymstoku z dnia 15 marca 2005 r., II SA/Bk 804/04, LEX nr 150811.

Wyrok WSA z dnia 14 listopada 2012 r., II SA/Gd 544/12, LEX nr 1228222.

Wyrok WSA z Wrocławia z dnia 30 listopada 2012 r., III SA/Wr 487/12, LEX nr 1249750.

Wyrok WSA w Poznaniu z dnia 5 listopada 2015 r., HYPERLINK „http://www. orzeczenia-nsa.pl/wyrok/i-sa-po-1753-15/sprawy_budzetowe_jednostek_samorzadu_terytorialnego_rozstrzygniecia_nadzorcze_dotyczace_gminy/32fc9f.html” I SA/Po 1753/15, LEX nr 1932546.

Streszczenie

Ustawodawca, kreując instytucję sekretarza gminy, stworzył swoistego pomocnika wójta, stojącego na straży prawidłowego funkcjonowania urzędu gminy i bezpośrednio mu podległego. Niniejszy artykuł ma na celu ukazanie roli, jaką sekretarz zajmuje w gminie, ze szczególnym zwróceniem uwagi na konstrukcje prawne dotyczące zajmowanego 
przez niego stanowiska. Ponadto podjęta została próba podziału i klasyfikacji zadań wykonywanych w praktyce przez sekretarza gminy.

Słowa klucze: sekretarz gminy, urząd gminy, organ wykonawczy, gmina, jednostka samorządu terytorialnego

\section{The Systemic Status of the Secretary of the Commune}

Abstract

By creating the institution of the secretary of the commune, the legislator created a helper of the commune head, a special assistant ensuring the proper functioning of the commune reporting directly to its head. The aim of this article is to introduce the role of the secretary in the commune with particular emphasis placed on legal constructions regarding the position occupied by the secretary of the commune. In addition, an attempt is made to divide and classify the tasks performed in practice by the secretary of the commune.

Keywords: secretary of the commune, communal office, the executive body of the commune, commune, local government unit 